\title{
A new species of the Y-larva genus Hansenocaris Itô, 1985 (Crustacea: Thecostraca: Facetotecta) from the Azores, with notes on its morphology and biogeography
}

\section{Новый виА Y-личинок рода Hansenocaris Itô, 1985 (Crustacea: Thecostraca: Facetotecta) с Азорских островов с обсуждением его морфологии и биогеографии}

\author{
Gregory A. Kolbasov ${ }^{1^{*}}$, Alexandra S. Savchenko ${ }^{2}$, Jens T. Hфeg ${ }^{3}$ \\ Григорий А. Колбасов ${ }^{1 *}$, Александра С. Савченко², Йенс Т. Хёг ${ }^{3}$
}

\footnotetext{
${ }^{1}$ White Sea Biological Station, Biological Faculty of Moscow State University, Moscow 119899, Russia: gakolbasov@gmail.com

${ }^{2}$ Invertebrate Zoology Department, Biological Faculty, Moscow State University, 119899, Moscow, Russia: as.savchenko1@gmail.com ${ }^{3}$ Marine Biology Section, Department of Biology, University of Copenhagen, Universitetsparken 4, DK-2100, Copenhagen, Denmark; jthoeg@bio.ku.dk

${ }^{1}$ Беломорская биологическая станция им. Н.А. Перцова, Биологический факультет МГУ, Ленинские горы 1-12, 119234, Москва

2 Кафедра Зоологии беспозвоночных, Биологический факультет МГУ, Ленинские горы 1-12, 119234, Москва

*Corresponding author
}

KEY WORDS: Facetotecta, Y-cypris, taxonomy, SEM, ultrastructure, distribution.

КЛЮЧЕВЫЕ СЛОВА: Facetotecta, Ү-циприс, таксономия, СЭМ, ультраструктура, распространение.

ABSTRACT. A new facetotectan species, described herein as Hansenocaris spiridonovi Kolbasov, Savchenko et Høeg sp.n. and based on its cypridiform stage, was found in the plankton off Azores Islands. We employed scanning electron microscopy to document the fine-scale external morphology of this species. We discuss the findings of facetotectan larvae showing cosmopolitan distribution of these crustaceans. The presence of Y-cyprid exuviae in plankton, findings of y-larvae in the deep sea plankton, occurrence in the oceanic plankton, as well as their permanent presence in the tropical waters may evidence on a pelagic host.

How to cite this paper: Kolbasov G.A., Savchenko A.S., Høeg J.T. 2021. A new species of the Y-larva genus Hansenocaris Itô, 1985 (Crustacea: Thecostraca: Facetotecta) from the Azores, with notes on its morphology and biogeography // Arthropoda Selecta. Vol.30. No.3. P.341-350. doi: 10.15298/arthsel. 30.3.07

РЕЗЮМЕ. Новый вид фасетотект Hansenocaris spiridonovi Kolbasov, Savchenko et Høeg sp.n. описан по циприсовидной личиночной стадии, обнаруженной в планктоне в прибрежной зоне Азорских островов. Морфология нового вида, включая ультраструктуру, была исследована с помощью сканирующей электронной микроскопии. Находки личинок фасетотект, свидетельствуют о космополитическом распространении этих ракообразных. Наличие экзувиев Y-циприсов в планктоне, находки Y-личинок в глубоководном и в океаническом планктоне, а также их постоянное присутствие в тропи- ческих водах могут свидетельствовать о пелагическом хозяине.

\section{Introduction}

The enigmatic Y-larvae represent the last significant group of Crustacea for which the adult forms are still unknown [Grygier, 1996; Kolbasov, Høeg, 2003; Glenner et al., 2008; Høeg et al., 2014; Kolbasov et al., 2021]. Their naupliar and cypridiform larvae have been found in the marine plankton worldwide. Grygier [1985] erected the higher-level taxon Facetotecta to accommodate Y-larvae and placed it inside the monophyletic Thecostraca. Different facetotectan nauplii from West Indian, equatorial Atlantic waters and from the Bay of Kiel in the Baltic were first described in detail more than 100 years ago by Hansen [1899]. Subsequently Y-larvae were reported from almost all oceans in the world [Kolbasov, Høeg, 2003; Belmonte, 2005; Ponomarenko, Korn, 2006; Swathi, Mohan, 2019]. A post-naupliar instar or 'Y-cyprid' resembling other thecostracan cypridiform larvae was first described by Bresciani [1965]. Treatment with the crustacean moulting hormone 20-hydroxy ecdysone induces Ycyprids to moult into a unique minute, slug-like stage, called the ypsigon [Glenner et al., 2008]. Thus, the incompletely known life cycle of Facetotecta includes free-swimming naupliar stages, a cypridiform larva specialized for attachment and an ypsigon with an unknown role [Pérez-Losada et al., 2009; Høeg et al., 2014]. The morphology of both the Y-cyprid and the ypsigon suggest that unknown adult stages are advanced 


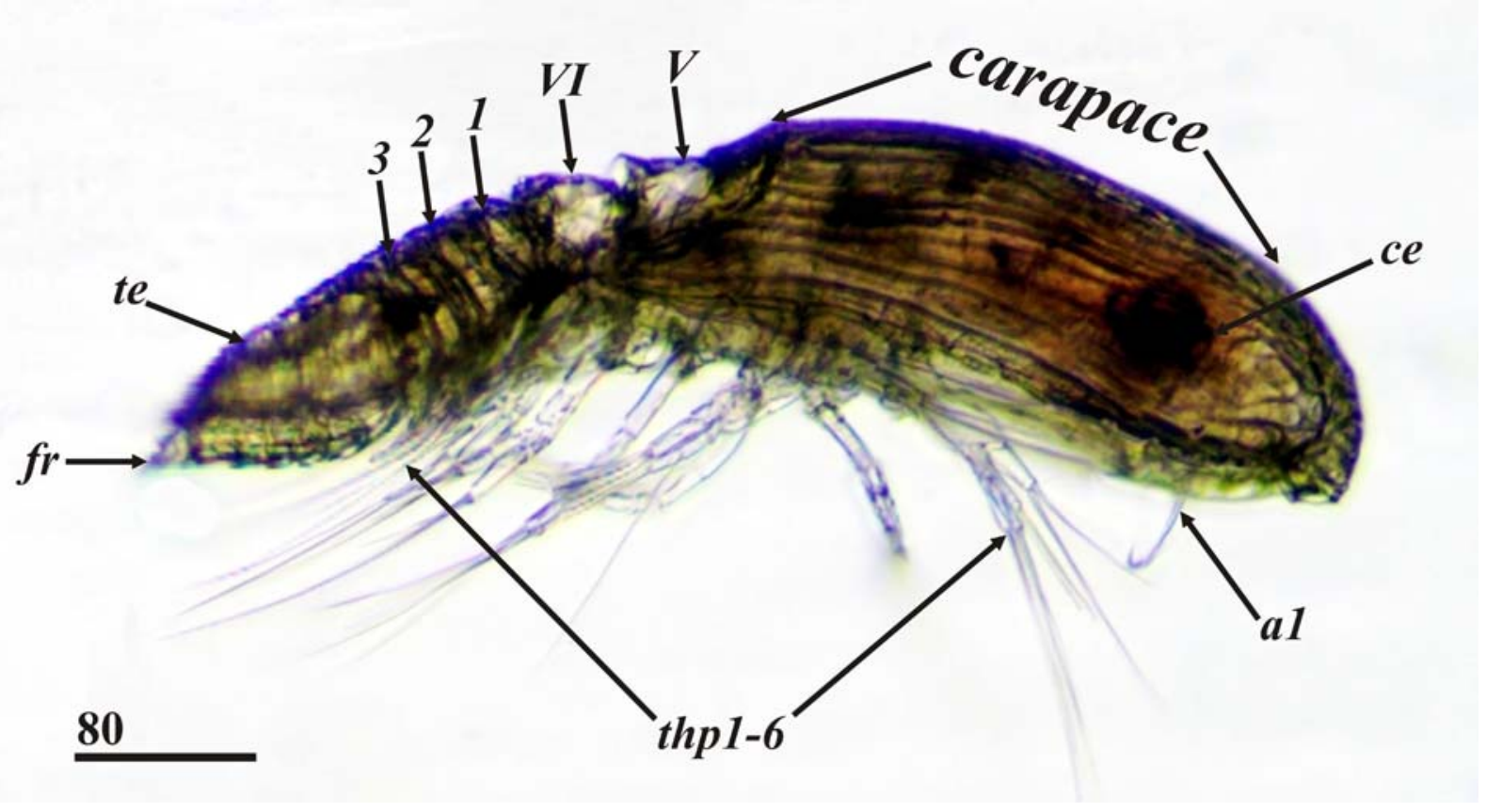

Fig. 1. Hansenocaris spiridonovi sp.n. General appearance, light microscopy, Y-cypris, holotype (ethanol fixation), thoracic segments numbered in Roman numerals, abdominal segments in Arabic numerals. Abbreviations: al — antennule, ce - compound (cypris) eye, fr furcal rami, te - telson, thp1-6 - thoracopods 1-6. Scale bars in $\mu \mathrm{m}$.

Рис. 1. Hansenocaris spiridonovi sp.n. Общий вид, световая микроскопия, Y-циприс, голотип, грудные сегменты пронумерованы римскими цифрами, брюшные сегменты - арабскими цифрами. Сокращения: al — антеннула, се — сложный глаз, $f r$ фуркальные ветви, te - тельсон, thp1-6 - торакоподы 1-6. Масштабная линейка в мкм.

endoparasites in still to be identified hosts [Glenner et al., 2008; Pérez-Losada et al., 2009]. The Y-nauplii can be planktotrophic (feeding) or lecithotrophic (nonfeeding), but the Y-cyprid is always non-feeding. At least thirteen naupliar morphotypes are known to date, but only some of these have been correlated with Ycyprids.

The naupliar body consists of a cephalic anterior part, covered by the dorsal head shield, and a posterior hindbody. The Y-cyprid has a univalved carapace that only partially covers the larval body, six pairs of natatory thoracopods, a segmented thorax and an abdomen with furcal rami. The dorsal side of the naupliar head shield, the 'trunk', the carapace, and the telson of the Y-cyprid have a surface pattern of reticulated cuticular ridges, which together form a series of interconnected plates or "facets".

Itô [1985] proposed the new genus Hansenocaris for three new species, described on the basis of their respective Y-cyprids. Currently, Facetotecta encompass seven species, established on the basis of Y-cyprid morphology and assigned to a single genus, Hansenocaris [Itô, 1990; Kolbasov et al., 2007]. Additional six species of Hansenocaris were described on the basis of naupliar stages [Steuer, 1905; Itô, 1985; Belmonte, 2005; Swathi, Mohan, 2019], but they remain dubious, because they were not established on the basis of Y-cyprid morphology.
A recent study revealed seven naupliar instars in Hansenocaris itoi Kolbasov et Høeg, 2003, instead of the five that were previously supposed for the Facetotecta [Kolbasov et al., 2021]. This number of naupliar instars is unique not only for Facetotecta, but also for Thecostraca and Hexanauplia as well.

Here, we describe a new species of Facetotecta from Azores, based on its cypridiform stage found in the plankton. We employ scanning electron microscopy to study its morphology in details. We discuss the findings of facetotectan larvae showing cosmopolitan distribution of these crustaceans. We dedicate this paper to our friend and colleague, Dr. Vassily A. Spiridonov, who passed away untimely after COVID-19 on 17.12.2020.

\section{Material and methods}

A single Y-cypris was found in the plankton off Azores Islands, Piscinas do Pesqueiro, Ponta Delgada. It was captured with a $72-\mu \mathrm{m}$ mesh net with $40 \mathrm{~cm}$ mouth opening at a depth of 0-2 $\mathrm{m}$ and preserved in 96\% ethanol. Before SEM examination it was studied with an Olympus BX51 light compound microscope. For SEM investigation it was dehydrated in acetone and critical-point-dried in $\mathrm{CO}_{2}$. The dried specimen was sputter-coated with an alloy of platinum-palladium and examined in a JEOL JSM-6380LA scanning electron microscope operating at voltages of $15-20 \mathrm{kV}$ at the University of Moscow. The resulting photographs were touched up using CorelDraw X3 Graphics Suite. 
Results

\section{TAXONOMIC PART}

Subclass Facetotecta Grygier, 1985

Genus Hansenocaris Itô, 1985

Hansenocaris spiridonovi Kolbasov, Savchenko et Høeg, sp.n.

Figs 1-5.

MATERIAL EXAMINED. One Y-cypris [holotype] collected in plankton by A.S. Savchenko and preserved in $96 \%$ ethanol. Collecting date: 18.07.2019. Type locality: Piscinas do Pesqueiro, Ponta Delgada, São Miguel Island, Azores $\left[37^{\circ} 44^{\prime} 21.4^{\prime \prime} \mathrm{N}, 25^{\circ} 39^{\prime}\right.$ $\left.41.1^{\prime \prime} \mathrm{W}\right]$, depth $0-2 \mathrm{~m}$. The holotype mounted on an SEM stub is deposited in the Zoological Museum of Moscow State University [no. Mg 1247]. A CD-ROM containing all the digital SEM photographs that were taken of the specimen has also been deposited there for permanent reference.

DIAGNOSIS. Y-cyprid having short carapace with prominent cuticular ridges, its posteriolateral corners short, not reaching the abdomen, areas adjoined to compound eyes inflated; antennules with conspicuous, curved claw and narrow, not bipartite aesthetasc; pleural extensions of thoracomeres 5 and 6 not developed; all thoracopods with twosegmented exo- and endopods; abdomen four-segmented, first segment lacking pointed posterioventral extensions; telson with four serrate spines along posterioventral margin.

ETYMOLOGY. The new species is named in honour of the distinguished Russian carcinologist and our friend Vassily A. Spiridonov, who made a great contribution to the study of malacostracan crustaceans before his untimely death after COVID-19 in 2020.

DESCRIPTION. General appearance. The body consists of a head, a six-segmented thorax, and a four-segmented abdomen (Figs 1, 2). The total length is app. $509 \mu \mathrm{m}$. The carapace covers the head and the anterior part of the thorax. The pair of large compound eyes lay laterally, $85 \mu \mathrm{m}$ from anteriormost end of carapace. It was impossible to trace in detail the number and positions of the ommatidia of the compound eyes. The labrum and antennules are situated on the ventral side of the head, under the compound eyes. Each thoracic segment bears a pair of biramous thoracopods. The fourth abdominal segment or telson is the largest, and it terminates in a pair of furcal rami.

Carapace (Figs 1, 2, 3). The short, univalved carapace is $284 \mu \mathrm{m}$ long along the mid-dorsal line and $326 \mu \mathrm{m}$ long along the lateral margins [ratio to the total length is 0.64] and only partially covering the dorsal and lateral sides of the larval body, with the rounded anterior end and posteriolateral corners extending to the anterior end of sixth thoracic segment (Figs 1,2). The areas of carapace adjoined to the compound eyes are inflated (Fig. 3, "ce"). The carapace resembles an inverted boat with the short posteriolateral parts somewhat produced and about $1 / 8$ of total carapace length. Long longitudinal and short transverse and oblique cuticular ridges are thick and prominent and occupy the whole surface of the carapace (Fig. 2). The surface of the carapace with numerous pores and pore-like pits in more or less a symmetrical pattern (Figs 3, 4A), comprising three major types. The first type has a slit-like opening enclosed by a conspicuous circular rim (Figs 3B, 4A). The second type is a deep pit with a round mouth from which a single short seta protrudes (Figs 3A, B, D). Small paired pores (including the terminal pores of the lattice organs $-t p$ ) and bigger unpaired, so-called central pores $(b p)$, all with round openings and lacking setae, belong to the third type (Fig. 3). There are at least 22 pairs of pores with cuticular rim of first type, 13 pairs of pits with seta inside, and four unpaired central pores in the mid-dorsal line: two anteriormost with cuticular rim and two big pores without rim associated with anterior and posterior pairs of the lattice organs (Fig. 3).

Lattice organs (Figs. 2B, 3B-D). The carapace bears five pairs of lattice organs $(l o)$, situated near the mid-dorsal line and grouped into two anterior and three posterior pairs. The anterior pairs (lo1 and lo2) surrounding the anterioriomost of the unpaired big central pores $40-55 \mu \mathrm{m}$ from the front end of the carapace (Figs 2B, 3A, B). The cuticle of the lattice organs is smooth and lacks any trace of small pores comprising a pore field. The first pair (lol) have a boomerang-like shape, about $11.7 \mu \mathrm{m}$ long and $2 \mu \mathrm{m}$ wide; they converge anteriorly, each narrows posteriorly towards the small terminal pore (Fig. 3B). The second pair (lo2) are elongate, about $19 \mu \mathrm{m}$ long and about $2 \mu \mathrm{m}$ wide; they converge slightly anteriorly and each narrows towards the small, posterior terminal pore (Fig. 3B). The posterior pairs of lattice organs (lo3-5) with small posterior terminal pores are situated near the posteriormost unpaired big central pore about $27 \mu \mathrm{m}$ from the rear margin, two conspicuous, deep pits with seta lie laterally (Figs 2B, 3C, D). The lo3 have teardrop-like form, each about $8.4 \mu \mathrm{m}$ long and $2.2 \mu \mathrm{m}$ wide, converge strongly anteriorly (Fig. 3C). The $l 04$ are almost parallel, with recurved posterior parts, each about $10.6 \mu \mathrm{m}$ long and $1.5 \mu \mathrm{m}$ wide (Fig. 3C, D). The lo5 are almost parallel and lie within conspicuous, posteriorly tapered, cuticular ridges or keels, each about $14 \mu \mathrm{m}$ long and $1.5 \mu \mathrm{m}$ wide (Fig. 3C, D).

Antennules (Figs 2C, 4A, B). Only the left antennule is exposed in the specimen. The antennules (Fig. 4A, B) consist of four segments, although the large, first segment is not observed. The second, horseshoe shaped segment is armed with a conspicuous curved hook ("claw") at the distal margin and a minute lateral seta on the outer surface (Fig. 4B). Exposed part of the third, short segment bears on the distal margin one short seta with bifid distal half, although other seta[e] maybe hidden (Fig. 4B). The fourth segment is small and armed terminally with one long, distally serrated seta, one minute or rudimentary seta and one thorn-like projection (Fig. 4A, B). Subterminally it also carries a long, narrow, not bipartite (without constriction) aesthetasc (Figs 2C, $4 \mathrm{~A}, \mathrm{~B})$.

Other cephalic structures. The distal part of the labrum has one anterior curved spine with proximal circular row of fine setules and four posterior long spines or hooks, (Figs. $2 \mathrm{C}, 4 \mathrm{~A}-\mathrm{C})$; the proximal part of labrum with two big unpaired pores and a pair of small pores at the base of posterior spines (Fig. 4C). A pair of postocular filamentary tufts is situated posteriorly to the antennules and labrum, each tuft consists of at least 10 setiform protrusions (Figs 2C, 4A). We did not find vestiges of antennae or mandibles, nor any trace of a pair of bifurcate paraocular processes associated with the compound eyes probably because they were hidden by the margins of carapace.

Thorax and thoracopods (Figs 1, 2, 4D). The thorax consists of six segments, their tergites with serrate posterior margins (Figs 1,2). We could not determine whether the tergites of the first two segments are dorsally fused [Grygier, 1987]. Each tergite is also bearing two or three transverse cuticular ridges (Fig. 2A, B). The tergites of the fifth and sixth thoracic segments have rudimentary quadrangular pleu- 


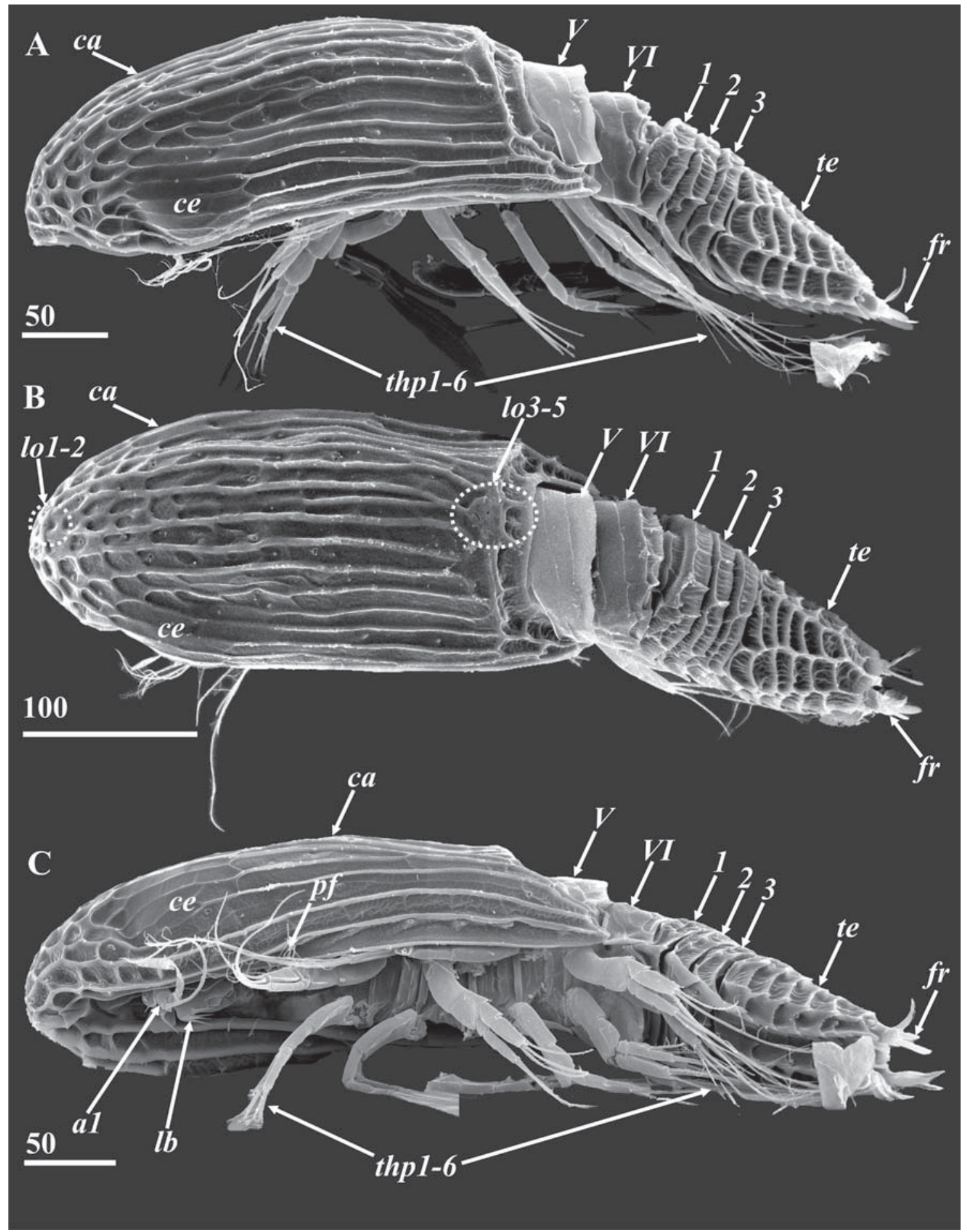

Fig. 2. Hansenocaris spiridonovi sp.n., y-cypris, holotype. General appearance [SEM], thoracic segments numbered in Roman numerals, abdominal segments in Arabic numerals: a - lateral view; $b$ - dorsal view, areas of lattice organs indicated on carapace with dotted oval outlines; $\mathrm{c}$ - ventrolateral view. Abbreviations: $a l$ - antennule, $c a$ - carapace, $c e-$ cuticle of carapace covering compound [cypris] eye, $f r$ - furcal rami, $l b$ - labrum, lo $1-5$ - lattice organs, $p f$ - postocular filamentary tuft, te - telson, thp $1-6$ - thoracopods 1-6. Scale bars in $\mu \mathrm{m}$.

Рис. 2. Hansenocaris spiridonovi sp.n., Y-циприс, голотип. Общий вид [СЭМ], грудные сегменты пронумерованы римскими цифрами, брюшные сегменты - арабскими цифрами: a - вид сбоку; b — вид сзади, области решетчатых органов обозначены на карапаксе пунктирными овальными контурами; с — вентролатеральный вид. Сокращения: $a 1$ - антеннула, $c a-$ карапакс, $c e-$ кутикула карапакса, покрывающая сложный глаз, $f r$ - фуркальная ветвь, $l b$ - лабрум, lol-5 - решётчатые органы, $p f-$ постокулярный пучок филаментов, te - тельсон, thp 1-6 - торакоподы 1-6. Масштабная линейка в мкм. 


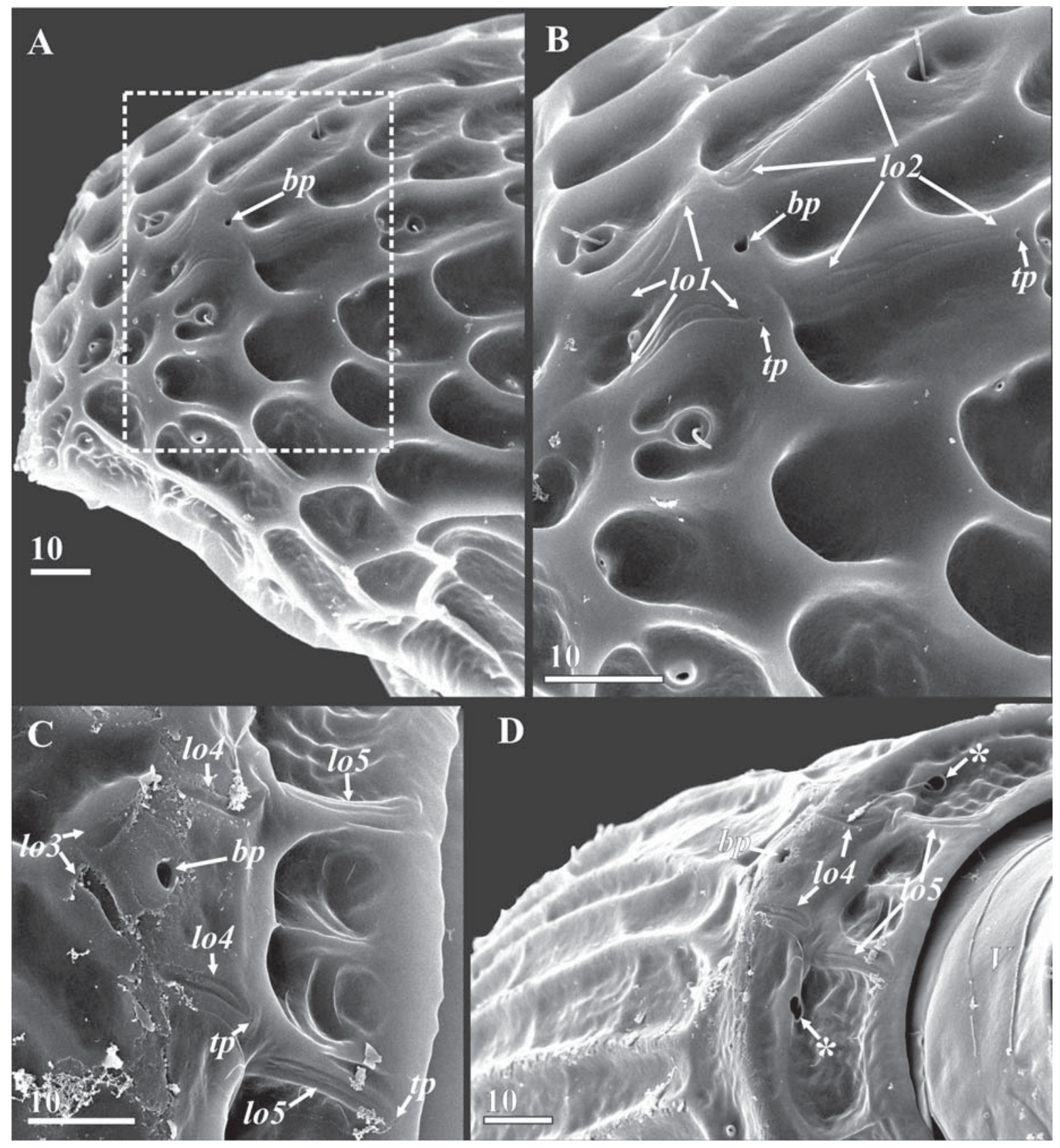

Fig. 3. Hansenocaris spiridonovi sp.n., y-cypris, holotype. Lattice organs of carapace [SEM]: a — anterior end of carapace with lattice organs; $\mathrm{b}$ - enlarged rectangular area from "A" with anterior pairs of lattice organs; $\mathrm{c}$ - posterior pairs of lattice organs; $\mathrm{d}$ - posterior margin of carapace with lattice organs, posteriodorsal view, deep pits with seta inside indicated by asterisk. Abbreviations: $b p-$ big central pore, $l o 1-5$ - lattice organs, $t p-$ terminal pore of lattice organs. Scale bars in $\mu \mathrm{m}$.

Рис. 3. Hansenocaris spiridonovi sp.n., Y-циприс, голотип. Решётчатые органы карапакса [CEM]: а - передний конец карапакса с решётчатыми органами; $b$ - увеличенная область рисунка "a" с передними парами решётчатых органов; c — задние пары решётчатых органов; $\mathrm{d}$ - задний край карапакса с решётчатыми органами, вид сзади, глубокие ямки с щетинкой внутри обозначены звёздочкой. Сокращения: $b p-$ большая центральная пора, lo1-5 - решётчатые органы, $t p-$ терминальная пора решётчатых органов. Масштабная линейка в мкм.

ral extensions (Fig. 2A). Each thoracomere bears a pair of biramous thoracopods.

Each thoracopod consists of a basal array of sclerites, a coxa, a basis, and a pair of rami [exopod and endopod]. All thoracopods have two-segmented exopods and endopods; coxa, basis and short proximal segments of both rami lack setae; elongated distal segments of both rami with long, setulated setae (Figs 1, 2A, C, 4D, 5A, B). The distal segments of both rami of first limb bearing two terminal setae (Fig. 2A, C). The distal segments of exopods of the remaining thoracopods (2-6) have three terminal setae; the distal segments of endopods with two terminal setae and one seta 


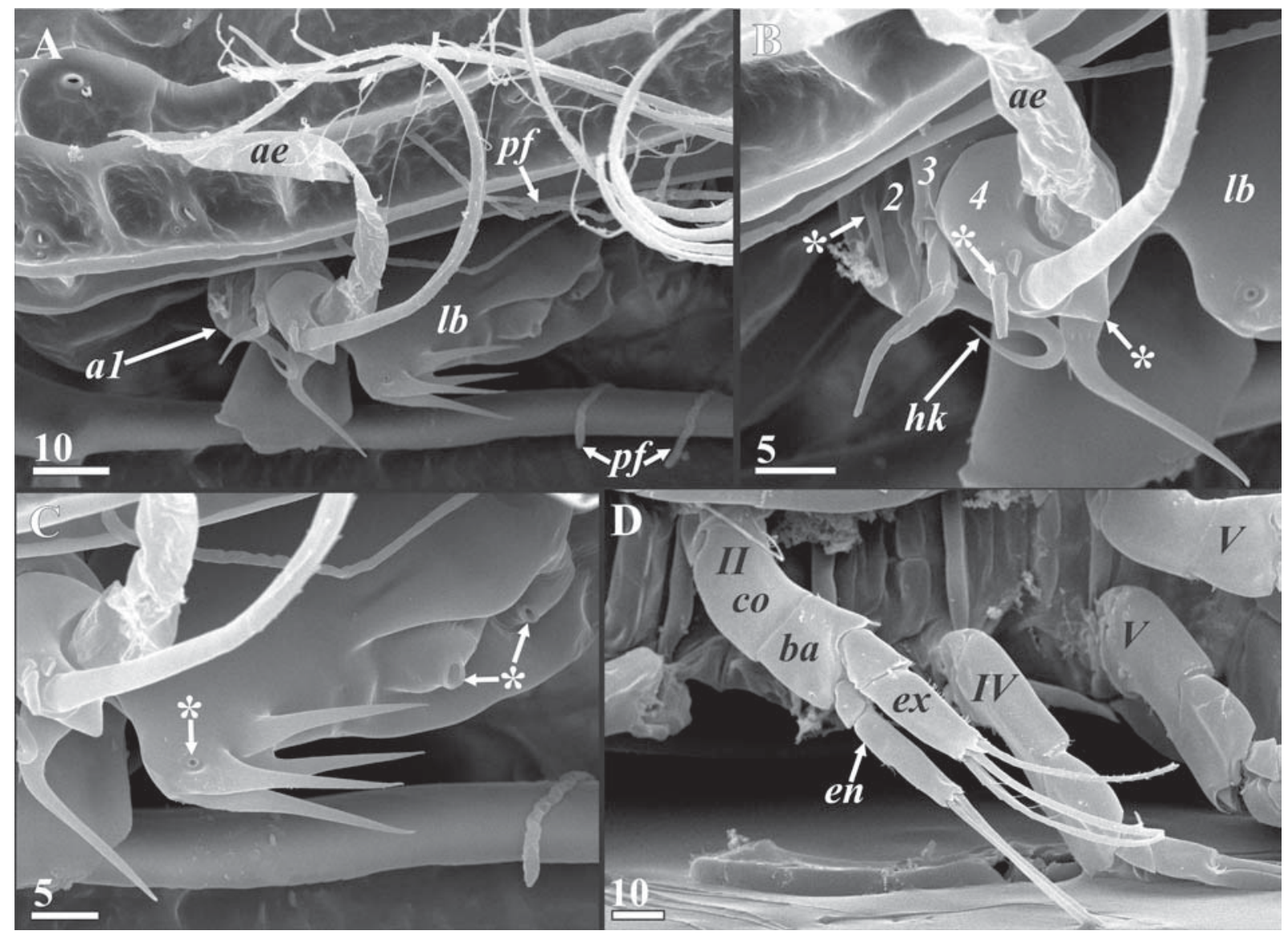

Fig. 4. Hansenocaris spiridonovi sp.n., y-cypris, holotype. Cephalic appendages and thoracopods [SEM]: a — cephalic appendages; b — antennule, distal part, rudimentary setae and "thorn" indicated by asterisks, antennular segments numbered in Arabic; c - labrum, lateral side, pores indicated by asterisks; $\mathrm{d}$ - thoracopods, numbered in Roman numerals. Abbreviations: $a 1$ - antennule, ae - aesthetasc, $b a$ — basis, co - coxa, en - endopod, ex - exopod, $h k$ - hook/claw of antennule, $l b$ - labrum, $p f$ - postocular filamentary tuft. Scale bars in $\mu \mathrm{m}$.

Рис. 4. Hansenocaris spiridonovi sp.n., Ү-циприс, голотип. Головные конечности и торакоподы [СЭМ]: а - головные придатки; $\mathrm{b}$ - антеннула, дистальная часть, рудиментарные щетинки и шиповидный вырост, обозначены звёздочками, членики антеннулы пронумерованы по-арабски; с — лабрум, вид сбоку, поры обозначены звёздочками; d — торакоподы пронумерованы римскими цифрами. Сокращения: a1 - антеннула, ае - эстетаск, ba - базис, со — кокса, en - эндоподит, ех - экзоподит, hk - крючок/ коготь антеннулы, lb - лабрум, pf - постокулярный пучок филаментов. Масштабная линейка в мкм.

at the middle of the inner margin [place of fusion of two endopod segments, Figs. 2C, 4D, 5B).

Abdomen (Figs 1, 2, 5). The abdomen consists of three short segments and a long telson with furcal rami. The abdominal segments have sculpture of transverse and longitudinal cuticular ridges and serrate margins, the tergites of the second and third segments have sharp and long pleural extensions absent in the first segment (Fig. 5A, B). The tergite of first segment has one pair of lateral pits with seta inside and one pair of dorsolateral pores; the tergite of second segment has one pair of lateral pores and tergite of third segment has one pair of pores on ventral surface of pleural extensions (Fig. 5A, B). The telson is densely covered by serrate cuticular ridges forming dorsal, lateral, and ventral rows of plates (Figs 2, 5A, B). Two dorsal rows consist of six and seven cuticular plates; each lateral side has two rows: laterodorsal and lateroventral with six cuticular plates each; the ventral surface consists of four longitudinal rows of plates (two ventrolateral and two ventromedial), ventrolateral rows have six plates and ventromedial rows have five plates (Figs 2, 5A, B). The surface of telson bears nine papilliform pores: one unpaired pore on seventh dorsal plate, paired pores on second and fourth laterodorsal plates, and paired pores on fourth and sixth ventrolateral plates (Fig. 5). Four conspicuous and serrate terminal spines project along the posterioventral border of the telson (Fig. 5).

A pair of short furcal rami is inserted in the posterior end of the telson (Figs 2, 5). Each ramus looks two-joined due to the conspicuous circular cuticular ridge but is rather unsegmented and carries three wide, lanceolate setae of different lengths, with serrate margins and basal papilla with pore (Fig. 5C, D].

COMPARISON. Seven described valid facetotectan species were established on the basis of Y-cypris characters, while the other six on the nauplius y phase [Steuer, 1905; Itô, 1985; Belmonte, 2005; Kolbasov et al., 2007; Swathi, Mohan, 2019]. Although the species established on the basis of the naupliar instars are distinguishable from one another, none are linked to any form of cypris y and none can be compared directly to previously described nominal species of Hansenocaris that are based on the cypris stage. These Y- 


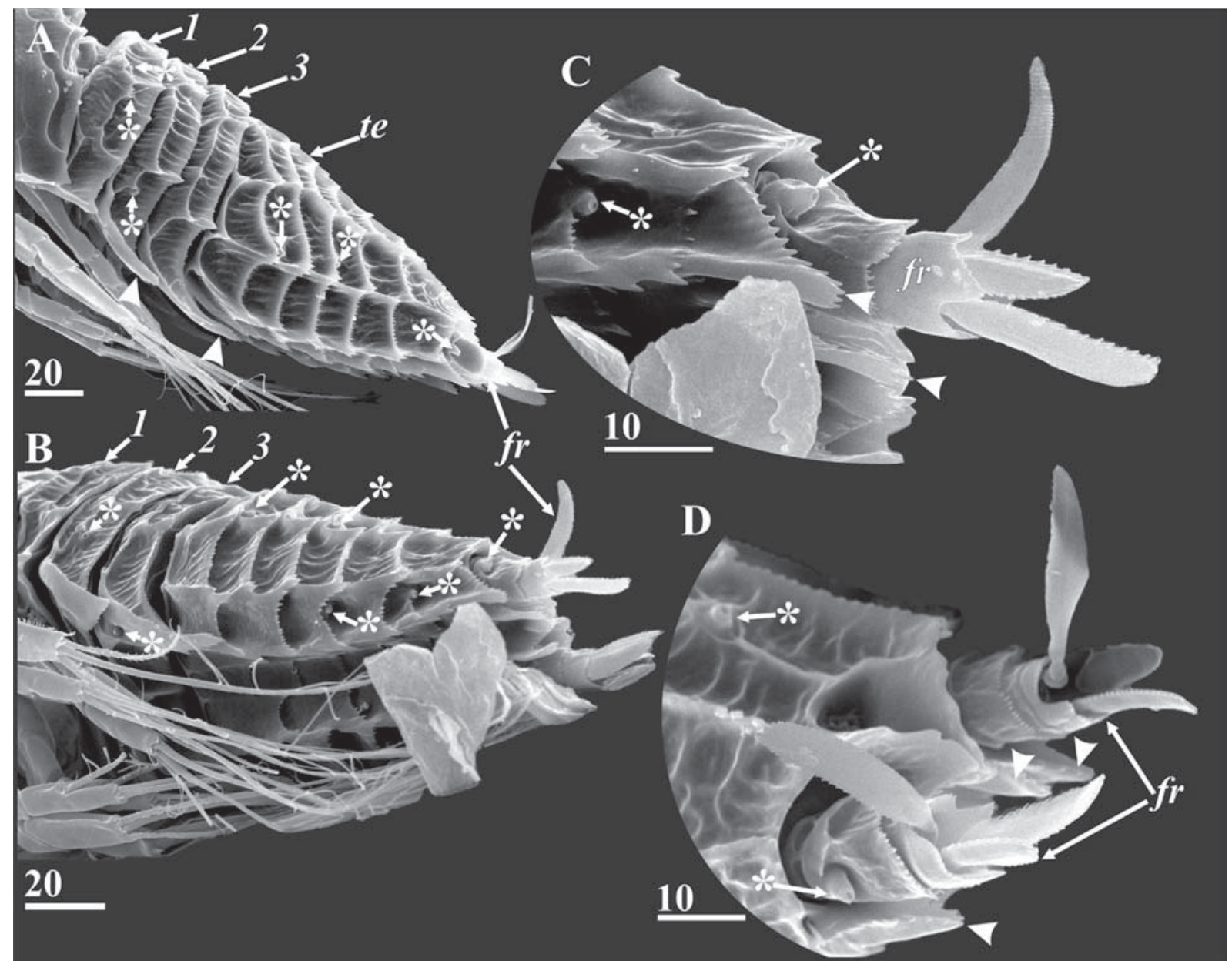

Fig. 5. Hansenocaris spiridonovi sp.n., y-cypris, holotype. Abdomen and furcal rami [SEM]: a — abdomen, lateral view, segments numbered in Arabic numerals, pores/papillae with pores indicated by asterisks, pleural extensions indicated by arrowheads; $b$ - abdomen, ventrolateral view, segments numbered in Arabic numerals, pores/papillae with pores indicated by asterisks.; c,d — furcal rami, lateral and dorsolateral view respectively, pores/papillae with pores indicated by asterisks, serrate terminal spines of telson indicated by arrowheads. Abbreviations: $f r$ - furcal rami, te - telson. Scale bars in $\mu \mathrm{m}$.

Рис. 5. Hansenocaris spiridonovi sp.n., Ү-циприс, голотип. Абдомен и фуркальные ветви (СЭМ): а - абдомен, вид сбоку, сегменты, пронумерованы арабскими цифрами, поры обозначены звёздочками, плевральные отростки, обозначены стрелками; $b$ абдомен, вентролатеральный вид, сегменты, пронумерованы арабскими цифрами, поры обозначены звёздочками; с, d — фуркальные ветви, латеральный и дорсолатеральный вид соответственно, поры обозначены звёздочками, зубчатые концевые шипы тельсона, обозначены стрелками. Сокращения: $f r$ - фуркальные ветви, $t e-$ тельсон. Масштабная линейка в мкм.

nauplii species represent the beginning of a parallel nomenclature [see Kolbasov et al., 2007].

Hansenocaris spiridonovi sp.n. in some characters, such as rounded anterior end of carapace with developed cuticular ridges and presence of the antennular hook, resembles facetotectan species of "Hansenocaris-pacifica group" including H. pacifica Itô, 1985 and H. furcifera Itô, 1989 from Japan, H. itoi Kolbasov et Høeg, 2003 from the White Sea and several undescribed Y-cyprids from Atlantic and Polar oceans and Kamchatka [Kolbasov, Høeg, 2003; Kolbasov et al., 2007; own data]. It can be easily distinguished from them in having a relatively shorter carapace, which does not reach the abdominal segments, shorter posteriolateral corners of carapace, developed and prominent cuticular ridges covering the whole carapace and rudimentary pleural extensions of fifth and sixth thoracomeres [Itô, Ohtsuka, 1984; Itô, 1989; Kolbasov, Høeg, 2003]. Hansenocaris spiridonovi sp.n. also differs from $H$. itoi in having not bipartite anten- nular aesthetasc, two-segmented endopods of the thoracopods 2-6 and four instead five serrate spines along the posterioventral margin of the telson. It differs from $\mathrm{H}$. pacifica by presence of four instead three serrate spines along the posterioventral margin of the telson and from $H$. furcifera by two-segmented endopods of the thoracopods 2-6 and four instead five serrate spines along the posterioventral margin of the telson.

A new species is distinguished from $H$. papillata Kolbasov et Grygier, 2007 described from Indonesia by the absence of a pair of papilliform protrusions at the anterior end of carapace, more developed cuticular ridges of carapace, presence of long and sharp pleural extensions of second and third abdominal segments and two-segmented endopods of thoracopods 2-6. Hansenocaris spiridonovi sp.n. is longer than $H$. rostrata, $H$. acutifrons, and $H$. tentaculata $(335-$ $375 \mu \mathrm{m})$ described from Japan [Itô, 1984, 1985, 1986]. All these species reportedly lack an antennular hook, whereas 


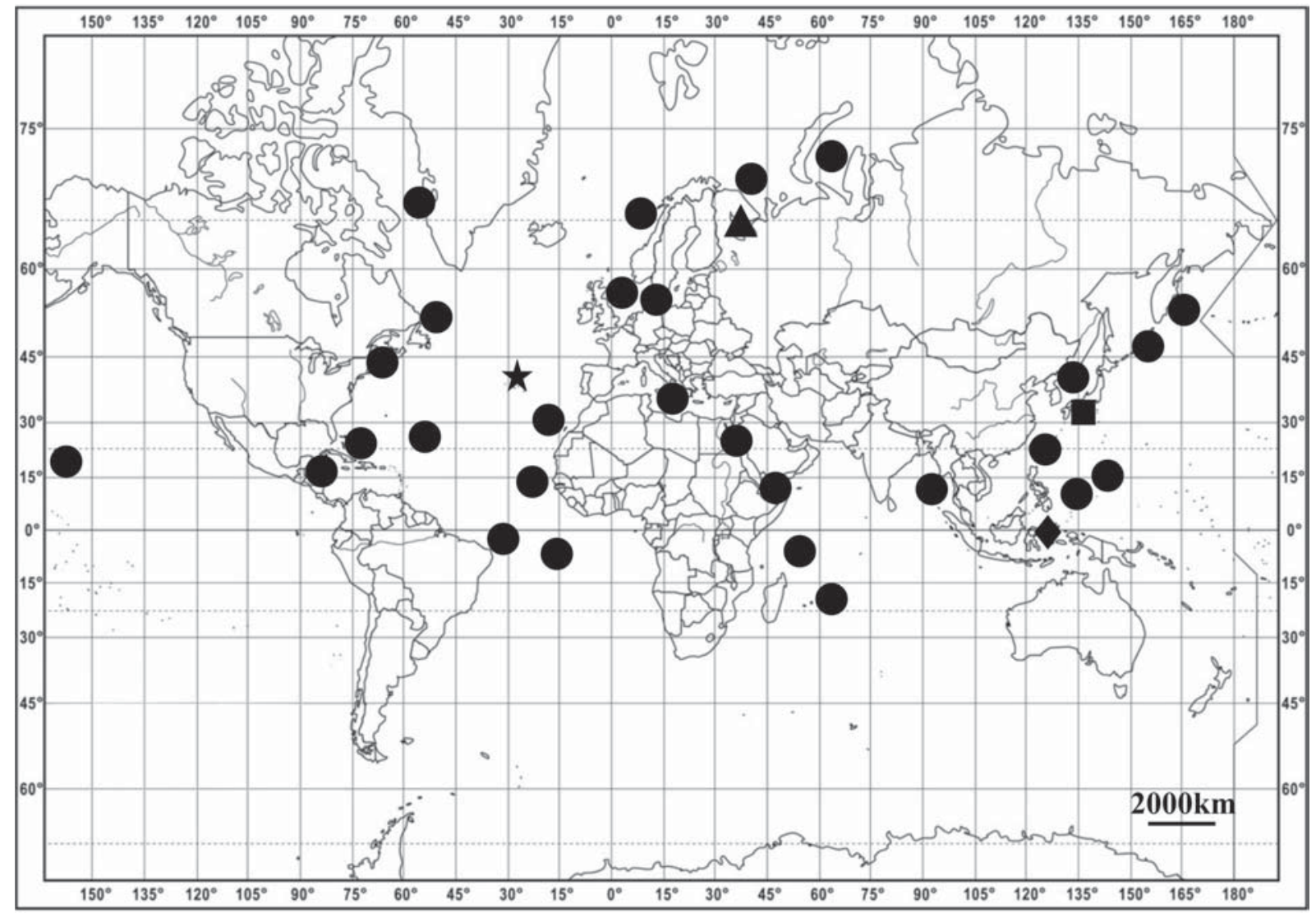

Fig. 6. Map of distribution (findings) of facetotectan larvae (locality of Hansenocaris spiridonovi sp.n. indicated by asterisk, rectangle H. acutifrons, $H$. furcifera, H.rostrata, $H$. pacifica, $H$. tentaculata, triangle $-H$. itoi, diamond - H. papillata, circle - unidentified y-cyprids and y-nauplii).

Рис. 6. Карта распространения личинок фасетотект (местонахождение Hansenocaris spiridonovi sp.n. обозначено звёздочкой, прямоугольник - H. acutifrons, $H$. furcifera, H. rostrata, H. pacifica, H. tentaculata, треугольник - H. itoi, ромб - H. papillata, круги - неописанные Ү-циприсы и Ү-науплиусы).

Hansenocaris spiridonovi sp.n. has a well-developed antennular hook. The anterior end of the carapace of H. rostrata and $H$. acutifrons is strongly produced in comparison with the rounded end in Hansenocaris spiridonovi sp.n. In addition, $H$. acutifrons and $H$. rostrata have six and five serrate spines along the posterioventral border of the telson respectively (four in new species), and $H$. tentaculata lacks such spines. $H$. tentaculata also has very long paraocular process and two-segmented abdomen, which distinguish this species from all other known facetotectans.

\section{Discussion}

The larvae of Facetotecta have a cosmopolitan distribution (Fig. 6). They have been found in all oceans and seas with normal or slightly reduced marine salinity (the White Sea - 21-25\% and western part of the Baltic Sea - 15-25\%o), where the plankton samples were examined for their presence. We did not find them in brackish waters of the Black Sea (14-17\%o) and central and eastern parts of the Baltic Sea (6-9\%o). The absence of facetotectans in the brackish waters may be connected with elimination from the local faunas of some taxa (e.g. the echinoderms and sponges) that may represent putative hosts of Y-larvae. Although Y-larvae can die at low salinity, while their putative hosts (not echinoderms or sponges) live in brackish waters and do not become infected with facetotectans there. In the Atlantic they are distributed from the equatorial regions [Hansen, 1899] to tropical [Bresciani, 1965; Grygier, 1996; Ohtsuka et al., 1999], subtropical and boreal [Hansen, 1899; Steuer, 1904; Apstein, 1905; McMurrich, 1917; Mileikovsky, 1968; Schram, 1972], and polar [Grygier, 1987]. In the Pacific Y-larvae were also found in equatorial [Kolbasov et al., 2007], tropical including Hawaii [Grygier, 1996, own data], subtropical and boreal regions [Mileikovsky, 1970; Itô, 1984, 1985, 1989; Grygier, 1996, Ponomarenko, Korn, 2006; own data]. In the Indian Ocean facetotectans were described from equatorial and tropical waters including the Red Sea, the Gulf of Aden and the Rodrigues, Seychelles and Andaman Islands [Almeida Prado-Por, Por, 1988; Böttger-Schnack, 1995; Conway et al., 2003; Swathi, Mohan, 2019]. In the Arctic Ocean Y-larvae were found in the Barents, White and Kara seas [Mileikovsky, 1968; Kolbasov, Høeg, 2003; own data]. 
Most of the Y-larvae were found in the neretic zone, near the continents, but some of them were reported from the oceanic plankton (mid-ocean) or from isolated islands such as Hawaii or St. Helena Island. Facetotectans mostly inhabit the continental shelf $(0$ $200 \mathrm{~m}$ ), but the deepest catches were collected in the Kuril-Kamchatka Trench between 3000-5640 m (bottom $5750 \mathrm{~m}$ ) and 3000-5900 m (bottom $8740 \mathrm{~m}$ ) (own data).

In tropical waters Y-larvae seem to be present more or less permanently [Almeida Prado-Por, Por, 1988, own data]. In the subtropical, boreal and even in polar waters they can be found most of the time of the year, except the White Sea where they were described from April to July, only. Thus, in the warm waters of Japan they were found from April to December [Grygier, 1996]; in the North, Baltic and Norwegian seas from January to November [Elofsson, 1971; Bresciani, 1965; Schram, 1972], in the boreal West Atlantic in February, April, May, June and December [McMurrich, 1917; Fish, Johnson, 1937] and in the polar region off the west coast of Greenland in July and October [Grygier, 1987].

In the south of Japan, the biodiversity of the Ylarvae exceeds more than thirty different species [Grygier, 1996; own data].

In the plankton facetotectans are represented by nauplii and cyridiform larvae, but occasionally their exuviae (including cyridiform) may be found. Thus, the cyridiform exuviae were found in Kamchatka and the Kara Sea (own data). Almeida Prado-Por and Por [1988] wrote about y-larvae that are permanently present in Gulf of Aqaba (Eilat): "We believe that the Hansenocaris cypris is either an adult animal, or is the young stage of a parasite on a plankton host: this is the only way in which their permanent presence in the plankton can be explained". Now we know that a unique minute, slug-like juvenile stage, called the ypsigon follows the Y-cyprids [Glenner et al., 2008]. But the presence of Y-cyprid exuviae in plankton, findings of Y-larvae in the deep sea plankton at the depths of 3000-5900 m but $2840 \mathrm{~m}$ above the bottom, occurrence in the oceanic plankton, as well as their permanent presence in the tropical waters may evidence on a pelagic host.

KeY to THE SPECIES OF FACETOTECTA DESCRIBED FROM THE CYPRIS Y STAGE

1. Abdomen two-segmented ....... Hansenocaris tentaculata

- Abdomen four-segmented ................................................... 2

2. Anterior end of carapace strongly produced, antennular hook absent ......

- Anterior end of carapace round or slightly produced, antennular hook present ..................................................... 4

3. Anterior end of carapace sharp, six telsonic spines ........... H. acutifrons

- Anterior end of carapace blunt, five telsonic spines H. rostrata

4. Carapace elongate, its posterior ends reaching abdomen

- Carapace short, its posterior ends not reaching abdomen
5. Anterior end of carapace with ventral papilliform protrusions, cuticular ridges feeble H. papillata

- Anterior end of carapace without ventral papilliform protrusions, cuticular ridges developed.

H. spiridonovi sp.n.

6. Antennular aesthetasc constricted at mid-length, posterior ends of carapace reaching telson .H. itoi

- Antennular aesthetasc not constricted at mid-length, posterior ends of carapace not reaching telson ................... 7

6. Entire surface of carapace covered by cuticular ridges ... H. pacifica

- Cuticular ridges absent in dorsal part of carapace ............ H. furcifera

Acknowledgements. We thank the collaborators of the Laboratory of Electronic Microscopy of Moscow State University for assistance in SEM studies. For GAK and ASS this work was financially supported by the Russian Foundation for Basic Research (grant 21-54-52003 MNT_a). We are indebted to anonymous referees for comments and criticism.

\section{References}

Almeida Prado-Por M.S., Por F.D. 1988. «Y» Crustacean larvae (order Facetotecta) in the plankton of the Gulf of Aqaba (Eilat), Red Sea // Rapports et procès-verbaux des réunions. Commision internationale pour l'exploration scientifique de la mer Méditerranée. Vol.31. No 2. P.302.

Apstein C. 1905. Plankton in Nord und Ostsee auf den deutschen Terminfahrten // Wissenschaftliche Meeresuntersuchungen der Commission zur wissenschaftlichen Untersuchung der deutschen Meere Abt. Kiel. Bd.9. S.1-26.

Belmonte G. 2005. Y-Nauplii (Crustacea, Thecostraca, Facetotecta) from coastal waters of the Salento Peninsula (south eastern Italy, Mediterranean Sea) with descriptions of four new species // Marine Biology Research. Vol.1. No.4. P.254-266. doi:10.1080/17451000500202518

Böttger-Schnack R. 1995. Summer distribution of micro- and small meso-zooplankton in the Red Sea and Gulf of Aden, with special reference to non-calanoid copepods // Marine Ecology Progress Series. Vol.118. P.81-102.

Bresciani J. 1965. Nauplius "y" Hansen: Its distribution and relationship with a new cypris larva // Videnskabelige Meddelelser fra Dansk Naturhistorisk Forening. Vol.128. P.245-258.

Conway D.V.P., White R.G., Hugues-Dit-Ciles J., Gallienne C.P., Robins D.B. 2003. Guide to the coastal and surface zooplankton of the south-western Indian Ocean // Occasional Publication of the Marine Biological Association of the United Kingdom. Vol.15. P.1-354.

Elofsson R. 1971. Some observations on the internal morphology of Hansen's nauplius y (Crustacea) // Sarsia. Vol.46. P.23-40.

Fish C.J., Johnson M.W. 1937. The biology of the zooplankton population in the Bay of Fundy and Gulf of Maine with special reference to production and distribution // Journal of the Biological Board of Canada. Vol.3. No 3. P.189-322.

Glenner H., Høeg J.T., Grygier M.J., Fujita Y. 2008. Induced metamorphosis in crustacean y-larvae: Towards a solution to a 100-year-old riddle // BMC Biology. Vol.6. No.21. P.1-6.

Grygier M.J. 1985. Comparative morphology and ontogeny of the Ascothoracida, a step toward a phylogeny of the Maxillopoda // Dissertation Abstracts International. Vol.45. P.2466B-2467B.

Grygier M.J. 1987. New records, external and internal anatomy, and systematic position of Hansen's y-larvae (Crustacea: Maxillopoda: Facetotecta) // Sarsia. Vol.72. P.261-278.

Grygier M.J. 1996. Classe des Thécostracés [Thecostraca Gruvel, 1905]. Sous-Classe des Facetotecta (Facetotecta Grygier, 1985). // Traité de Zoologie. Vol.7(2). Crustacés: Généralités [suite] et Systématique [1re partie]. P.425-432. 
Hansen H.J. 1899. Die Cladoceren und Cirripedien der Plankton Expedition // Ergebnisse der Plankton Expedition der Humboldt Stiftung. Bd.T2(G, d). S.S1-58.

Høeg J.T., Chan B.K.K., Kolbasov G.A., Grygier M.J. 2014. Facetotecta // Martin J., Olesen J., Høeg J.T. (eds.). Atlas of Crustacean Larvae. Baltimore: Johns Hopkins University Press. P.100 103.

Itô T. 1984. Another cypris y from the North Pacific, with reference to the bending behavior exhibited by a cypris y specimen of the formerly described type (Crustacea: Maxillopoda) // Publications of the Seto Marine Biological Laboratory. Vol.29. No. 4/6. P.367-374.

Itô T. 1985. Contributions to the knowledge of cypris y (Crustacea: Maxillopoda) with reference to a new genus and three new species from Japan // Special Publication of the Mukaishima Marine Biological Station. P.113-122.

Itô T. 1986. A new species of "cypris y" (Crustacea: Maxillopoda) from the North Pacific. Publications of the Seto Marine Biological Laboratory. Vol.31. No.3/6. P.333-339.

Itô T. 1989. A new species of Hansenocaris (Crustacea: Facetotecta) from Tanabe Bay, Japan // Publications of the Seto Marine Biological Laboratory. Vol.34. No.1/3. P.55-72.

Itô T. 1990. Naupliar development of Hansenocaris furcifera Itô (Crustacea: Maxillopoda: Facetotecta) from Tanabe Bay, Japan // Publications of the Seto Marine Biological Laboratory Vol.34. No.4/6. P.201-224.

Itô T., Ohtsuka S. 1984. Cypris y from the North Pacific (Crustacea: Maxillopoda) // Publications of the Seto Marine Biological Laboratory. Vol.29. No.1/3. P.179-186.

Kolbasov G.A., Høeg J.T. 2003. Facetotectan larvae from the White Sea with the description of a new species (Crustacea: Thecostraca) // Sarsia. Vol.88. P.1-15

Kolbasov G.A., Grygier M.J., Ivanenko V.N., Vagelli A.A. 2007. A new species of the y-larva genus Hansenocaris Itô, 1985 (Crustacea: Thecostraca: Facetotecta) from Indonesia, with a review of y-cyprids and a key to all their described species // The Raffles Bulletin of Zoology. Vol.55. No.2. P.343-353.

Kolbasov G.A., Petrunina A.S., Dreyer N., Prudkovsky A.A., Olesen J., Chan B.K.K., Høeg J.T. 2021. Naupliar development of
Facetotecta (Crustacea: Thecostraca) and the nature of the first nauplius instar in the Crustacea - pro et contra the Hexanauplia concept // Organisms Diversity \& Evolution. Vol.21. No.1. P.1-22. doi.org/10.1007/s13127-021-00479-y

McMurrich J.P. 1917. Notes on some Crustacean forms occurring in the Plankton of Passamaquoddy Bay // Transactions of the Royal Society of Canada. Ser.3. Vol.11 (Section 4). P.47-61.

Mileikovsky S.A. 1968. Distribution of pelagic larvae of bottom invertebrates of the Norwegian and Barents Seas // Marine Biology. Vol.1. No.3. P.161-167.

Mileikovsky S.A. 1970. [Distribution of pelagic larvae of bottom invertebrates in the Kurile-Kamchatka area] // Trudy Instituta Okeanologii. Vol.86. P.117-133 [in Russian].

Ohtsuka S., Grygier M.J., Torigo K. 1999. [The phylogeny, zoogeography, and ecology of marine cavernicolous crustaceans] // Taxa. Vol.6. P.3-13 [in Japanese with English abstract].

Pérez-Losada M., Høeg J.T., Crandall K.A. 2009. Remarkable convergent evolution in specialized parasitic Thecostraca (Crustacea) // BMC Biology. Vol.7. No.15. P.1-12.

Ponomarenko E.A., Korn O.M. 2006. First record of a Facetotectan crustacean in plankton of Peter the Great Bay, Sea of Japan // Russian Journal of Marine Biology Vol.32. P.299-301. doi.org/ 10.1134/S1063074006050063

Schram T.A. 1972. Further records of nauplius y type IV Hansen from Scandinavian waters // Sarsia. Vol.50. P.1-24.

Steuer A. 1904. Mitteilungen aus der k.k. zoologischen Station in Triest. Nr. 9. Über zwei interessante Larvenformen aus dem Plankton des Triester Golfes // Zoologischer Anzeiger. Bd.28. H.7. S.228-230.

Steuer A. 1905. Über eine neue Cirripedienlarve aus dem Golfe von Triest // Arbeiten aus den Zoologischen Instituten der Universität Wien und der Zoologischen Station in Triest. Bd.15. H.2. S.113-118.

Swathi V., Mohan P.M. 2019. Identification of Y-Nauplii (Facetotecta) in Andaman Sea, India // Open Journal of Marine Science. Vol.9. P.137-147. doi: 10.4236/ojms.2019.93011

Responsible editor I.N. Marin 